\title{
Vanadium complex: an appropriate candidate for killing hepatocellular carcinoma cancerous cells
}

\author{
Hamid Bakhshi Aliabad • Soudeh Khanamani Falahati-pour · Hadis Ahmadirad • \\ Maryam Mohamadi • Mohammad Reza Hajizadeh • Mehdi Mahmoodi
}

Received: 19 March 2018/Accepted: 4 September 2018/Published online: 25 September 2018

(C) The Author(s) 2018

\begin{abstract}
Hepatocellular carcinoma (HCC) is a prevalent human malignancy which its drug resistance is increasing world-wide. This project was designed to assess the anti-cancer effects of 4-bromo-2-(( (5chloro-2-hydroxyphenyl) imino) methyl) phenol ([IV(L)] complex) on the HepG2 cell line and also L929 cells, as normal cells. HepG2 and L929 cells were cultured in RPMI culture medium and the survival rates of the cells were determined after 24 and $48 \mathrm{~h}$ using MTT assay to find IC50 concentration of vanadium $\mathrm{m},[\mathrm{IV}(\mathrm{L})]$ complex. The early apoptosis and necrosis/late apoptosis were determined by means of annexin V/PI apoptosis detection kit. The results
\end{abstract}

H. Bakhshi Aliabad · H. Ahmadirad .

M. R. Hajizadeh · M. Mahmoodi

Molecular Medicine Research Center, Research Institute of Basic Medical Sciences, Rafsanjan University of

Medical Sciences, Rafsanjan, Iran

S. Khanamani Falahati-pour · M. Mohamadi

Pistachio Safety Research Center, Rafsanjan University of

Medical Sciences, Rafsanjan, Iran

M. R. Hajizadeh · M. Mahmoodi

Department of Clinical Biochemistry, Faculty of

Medicine, Rafsanjan University of Medical Sciences,

Rafsanjan, Iran

M. Mahmoodi ( $₫)$

Department of Clinical Biochemistry, Afzalipoor Faculty of Medicine, Kerman University of Medical Sciences,

Kerman, Iran

e-mail: mahmoodies@yahoo.com revealed that vanadium $\mathrm{m},[\mathrm{IV}(\mathrm{L})]$ complex induce early apoptosis higher in HepG2 cell line than L929 cells. The rates of necrosis/late apoptosis were also induced in HepG2 cells more than L929 cells. Based on the results, vanadium $\mathrm{m}$, $[\mathrm{IV}(\mathrm{L})]$ complex might be considered as a safe new drug for treatment of HCC with low side effects on control liver cells.

Keywords Vanadium complex $\cdot$ HepG2 cells $\cdot$ L929 cells $\cdot$ Hepatocellular carcinoma $\cdot$ Cytotoxicity

$\begin{array}{ll}\begin{array}{l}\text { Abbreviations } \\ \text { HCC }\end{array} & \\ \text { Vanadium m, [IV(L)] } & \begin{array}{l}\text { Hepatocellular carcinoma } \\ \text { IV complex with 4-bromo-2- } \\ (((5-c h l o r o-2-\end{array} \\ & \begin{array}{l}\text { hydroxyphenyl) imino }) \\ \text { methyl) phenol (L) }\end{array} \\ \text { FBS } & \begin{array}{l}\text { Fetal bovine serum } \\ \text { Ethylene diamine tetra acetic } \\ \text { acid }\end{array} \\ \text { EDTA } & \begin{array}{l}\text { 3-(4,5-Dimethylthiazol-2- } \\ \text { yl)-2,5- diphenyl tetrazolium } \\ \text { bromide }\end{array} \\ \text { MTT } & \end{array}$

\section{Introduction}

It has been demonstrated that cancers are the main cause of mortality in the human population (Winters 
et al. 2017; Tervonen et al. 2017). The Liver is a main organ which can be suffered from cancers which are induced by several factors such as drugs, viruses and chronic inflammation (Ho et al. 2016). Several therapeutic approaches have been introduced for the treatment of cancers including hepatocellular carcinoma (HCC) including radiotherapy, chemotherapy and immunotherapy (Shiba et al. 2017; Obeid et al. 2017). Chemotherapy is a famous approach which is used for the treatment of several cancers including HCC (Le Grazie et al. 2017). However, the current drugs which are used for chemotherapy are associated with several side effects which are derived from their effects on the normal non-cancerous cells (Le Grazie et al. 2017; Ceylan et al. 2015; Clavagnier 2014; Hosseini et al. 2017; Zainodini et al. 2018). Therefore, investigators have been trying to find new therapeutic strategies for cancer treatment with the lowest side effects (Sheikhrezaei et al. 2018; Karimabad et al. 2017; Ramezani et al. 2017; Mohammadizadeh et al. 2018). Based on the fact that HCC is a prevalent cancer word-wide, hence, several studies are designed to introduce new chemotherapy strategies to overcome the disease. Accordingly, several liver cell lines, including HepG2, have been introduced by investigators to examine new drugs for the treatment of HCC (Han et al. 2015). Thus, this cell line has been used in several studies to examine the effectiveness of new anti-cancer drugs.

It has been proposed that vanadium (IV), a metal ion complex, is a suitable candidate for cancer treatment (Nair et al. 2014). It appears that vanadium IV has lower side effects than platinum metal ions (Leon et al. 2017a), hence, recent investigations are focused on the IV complexes to find a suitable drug with the lowest side effects on normal non-cancerous cells. Vanadium compounds as a new class of non-platinum metallodrugs have attracted much attention and large efforts have been made to discover new molecular targets of these compounds (Leon et al. 2017a; León et al. 2016; Sciortino et al. 2018; Ebrahimipour et al. 2015; Abbasi et al. 2017; Hong et al. 2017; Schmidt et al. 2017; Sheikhshoaie et al. 2016; Ebrahimipour et al. 2016; Nair et al. 2016; Takjoo et al. 2013; Takjoo et al. 2017; Heidari et al. 2017; Zabin and Abdelbaset 2016; Mohamadi et al. 2015).

Several mechanisms have been proposed for IV complexes to overcome cancer cells including upregulation of free radical reactions which is toxic for cancer and normal cells (Wang et al. 2010) altered expression molecules involved in the phosphoinositide-3-kinase-protein kinase B/Akt (PI3K-PKB/Akt), p21 activated protein kinases (PAK), death-associated protein kinase (DAPK), cyclin-dependent kinase (CDK) 4, 6 and 7, Fas-associated protein with death domain (FADD), protein 2-alpha (AP2), and c-Jun $\mathrm{N}$-terminal kinase (JNK) signaling pathways (Leon et al. 2016) and the several molecules such as B cell lymphoma-extra (Bcl-x), Caspase 3 (CASP3), CASP6, CASP7, CASP10 and CASP11 (Leon et al. 2017b). However, the effectiveness of the anti-cancer metals on HCC and also their side effects on normal cells need to be explored by further investigations.

Based on the fact that HepG2 is a well-known cell line for using in $\mathrm{HCC}$ related investigations, hence, the main purpose of this study was to appraise the anticancerous effects of an IV complex with 4-bromo-2(((5-chloro-2-hydroxyphenyl) imino) methyl) phenol (L), which abbreviate to $[\mathrm{IV}(\mathrm{L})]$ complex, on the HepG2 cell line. On the other hand, due to the various side effects of chemotherapy on the normal cells of the hosts, another goal of this study was to explore the effects of the $[\mathrm{IV}(\mathrm{L})]$ complex on the survival and apoptosis of L929, a normal cell line.

\section{Materials and methods}

Material and instrumentations

\section{Cell lines}

Human cancerous (HepG2) and mouse fibroblast L929 cell lines have been purchased from Pasture Institute, Tehran, Iran.

\section{Cell culture}

The HepG2 and L929 cell lines were cultured in the RPMI 1640 culture medium containing $10 \%$ of fetal bovine serum (FBS), $100 \mathrm{IU} / \mathrm{mL}$ penicillin and $100 \mu \mathrm{g} / \mathrm{L}$ streptomycin, and incubated in a $5 \% \mathrm{CO}_{2}$ incubator at $37{ }^{\circ} \mathrm{C}$ (Memert Company, Germany) (Bagrezaei et al. 2018). To use the cells for examination regarding survival, apoptosis and treatment with the $[\mathrm{IV}(\mathrm{L})]$ complex, the growth cells were separated from culture falcons using trypsin-Ethylene diamine tetra acetic acid (EDTA) and centrifuged at $1100 \mathrm{rpm}$ for $5 \mathrm{~min}$. Then, $1 \mathrm{~mL}$ fresh RPMI medium was used 
to make a suspension from the precipitated cells to determine the survived cells percent via MTT assay (Roche CO. Mannheim, Germany) and determination of inhibiting cell growth by $50 \%$ (IC50).

Preparation of 4-bromo-2-(((5-chloro-2-

hydroxyphenyl)imino)methyl)phenol (H2L)

Five milliliter of an ethanolic solution containing $0.03 \mathrm{~g}(0.2 \mathrm{mmol})$ 2-amino-4-chlorophenol was added to $5 \mathrm{~mL}$ solution of equimolar quantity of 2-hydroxy-5bromobenzaldehyde in ethanol while stirring vigorously. After refluxing the mixture for $30 \mathrm{~min}$, a red precipitate (H2L) was formed. The product was separated by filtration, washed with cold ethanol, and dried in a desiccator over anhydrous $\mathrm{CaCl}_{2}$.

m.p.: $199{ }^{\circ} \mathrm{C}$. Anal. Calcd for $\mathrm{C}_{3} \mathrm{H}_{9}$ $\mathrm{BrClNO}_{2}\left(326.57 \mathrm{~g} \mathrm{~mol}^{-1}\right): \mathrm{C}, 47.81 ; \mathrm{H}, 2.87 ; \mathrm{N}$, 4.29. Found: C, 47.79; H, 2.82; N, 4.32\%. FT-IR (KBr) cm: $v(\mathrm{OH}) \quad 3445, v(\mathrm{~N}-\mathrm{H}) \quad 3131, v(\mathrm{C}=\mathrm{N})$ 1627, $v(\mathrm{C}=\mathrm{Cring}) \quad 1580, \quad v(\mathrm{C}-\mathrm{O}) \quad 1320, v(\mathrm{C}-\mathrm{Cl})$ 680, v(C-Br) 585 .

Preparation of (2,2'-bipyridine)[4-bromo-2-((5chloro-2- hydroxyphenylimino)methyl)phenol] oxido-vanadium(IV) [VOL(bipy)]

To $6 \mathrm{~mL}$ hot methanolic solution of $\mathrm{H} 2 \mathrm{~L}(0.1 \mathrm{mmol}$, $0.03 \mathrm{~g})$, an equimolar amount of $\mathrm{VOSO}_{4} \cdot 3 \mathrm{H}_{2} \mathrm{O}$ $(0.1 \mathrm{mmol}, 0.02 \mathrm{~g})$ was added. A brown solution was obtained which was refluxed for $1 \mathrm{~h}$. After adding $0.1 \mathrm{mmol}(0.02 \mathrm{~g})$ of $2,2^{\prime}$-bipyridine to the mixture, the reflux was continued for further $3 \mathrm{~h}$. Slow evaporation of the solvent resulted in suitable single crystals [VOL(bipy)]. The product was separated, washed with cold ethanol, and dried in a vacuum desiccator over $\mathrm{CaCl}_{2}$.

m.p.: $236{ }^{\circ} \mathrm{C}$. Molar conductivity $\left(1.0 \times 10^{3} \mathrm{M}\right.$, DMSO): $20.8 \Omega^{-1} \mathrm{~cm}^{-2} \mathrm{~mol}^{-1}$. Anal. Calcd for $\mathrm{C}_{24-}$ $\mathrm{H}_{19} \mathrm{BrClN}_{3} \mathrm{O}_{4} \mathrm{~V}\left(579.72 \mathrm{~g} \mathrm{~mol}^{-1}\right)$ : C, 49.72; H, 3.30; N, 7.25. Found: C, 49.67; H, 3.28; N, 7.29\%. FT-IR (KBr) $\mathrm{cm} 1: \mathrm{v}(\mathrm{C}=\mathrm{N}) \quad 1596, \mathrm{v}(\mathrm{C}=\mathrm{Cring}) 1511 \mathrm{~s}, \mathrm{v}(\mathrm{C}-\mathrm{O})$ $1289 \mathrm{~m}, \mathrm{v}(\mathrm{V}=\mathrm{O}) 949 \mathrm{~s}, \rho$ (pyring) $905 \mathrm{~m}, \mathrm{v}(\mathrm{C}-\mathrm{Cl})$ $701 \mathrm{~m}, \mathrm{v}(\mathrm{C}-\mathrm{Br}) 647 \mathrm{w}$.

FTIR spectral data

In the IR spectrum of $\mathrm{H} 2 \mathrm{~L}$, the band appeared at $3131 \mathrm{~cm}^{-1}$ was assigned to the NH...O stretching vibration confirming the keto form of the ligand in the solid state. In solution, however, the enol tautomer was the prominent form of the ligand. After the loss of the enolic proton in complexation process, a dianionic ligand was produced (L2-). The band attributed to azomethine moiety was observed at $1627 \mathrm{~cm}^{-1}$ in the $\mathrm{H} 2 \mathrm{~L}$ spectrum and at $1596 \mathrm{~cm}^{-1}$ in the [VOL(bipy)] spectrum. This shift suggested the coordination of the azomethine nitrogen to the V(IV) ion. Due to the coordination, the $\mathrm{C}-\mathrm{O}$ vibration appeared at $1320 \mathrm{~cm}^{-1}$ in the ligand shifted to $1289 \mathrm{~cm}^{-1}$ in the V(IV) complex confirming the coordination of the oxygen to the metal central ion. The $\mathrm{V}=\mathrm{O}$ vibration of the vanadyl was observed at $949 \mathrm{~cm}^{-1}$ (Fig. 1).

\section{3-(4,5-Dimethylthiazol-2-yl)-2,5-diphenyl tetrazolium bromide (MTT) assay}

The MTT cell proliferation assay was used to determine IC50 for the [IV(L)] complex. Briefly, HepG2 and L929 cells were seeded at a density of $1 \times 10^{4}$ cells/well and treated with the $[\mathrm{IV}(\mathrm{L})]$ complex at several concentrations for 24 and $48 \mathrm{~h}$. Accordingly, $10 \mu \mathrm{L}$ MTT $(5 \mathrm{mg} / \mathrm{mL}$ ) (Roche CO. Mannheim, Germany) was added to each wells and incubated at $37^{\circ} \mathrm{C}$ for $1 \mathrm{~h}$ After solving of formazan crystal in 200 $\mu \mathrm{L}$ of DMSO, the absorbance of the samples was measured at $570 \mathrm{~nm}$ with background subtraction at $630 \mathrm{~nm}$. The IC50 of the [IV(L)] complex for HepG2 and L929 cell lines were then calculated to use for analysis of apoptosis by Annexin-V/PI apoptosis detection kit (Ebioscience, CA, USA). To evaluate the time-dependent effect, viability of HepG2 and L929 cells at IC50 value was determined at both 24 and $48 \mathrm{~h}$.

Apoptosis evaluation

\section{Annexin-V-FITC and propidium iodide for analysis of apoptosis}

Apoptosis was determined using a commercial annexin V-FITC/PI apoptosis detection kit (eBioscience Co. San Diego, CA, USA). Accordingly, the seeded HepG2 and L929 cells which were pre-treated with IC50 concentration of the [IV(L)] complex for 24 and $48 \mathrm{~h}$, were harvested and washed using cold PBS. The washed cells were incubated with $500 \mu \mathrm{L}$ binding buffer which contains $1.25 \mu \mathrm{L}$ of annexin V-FITC and 

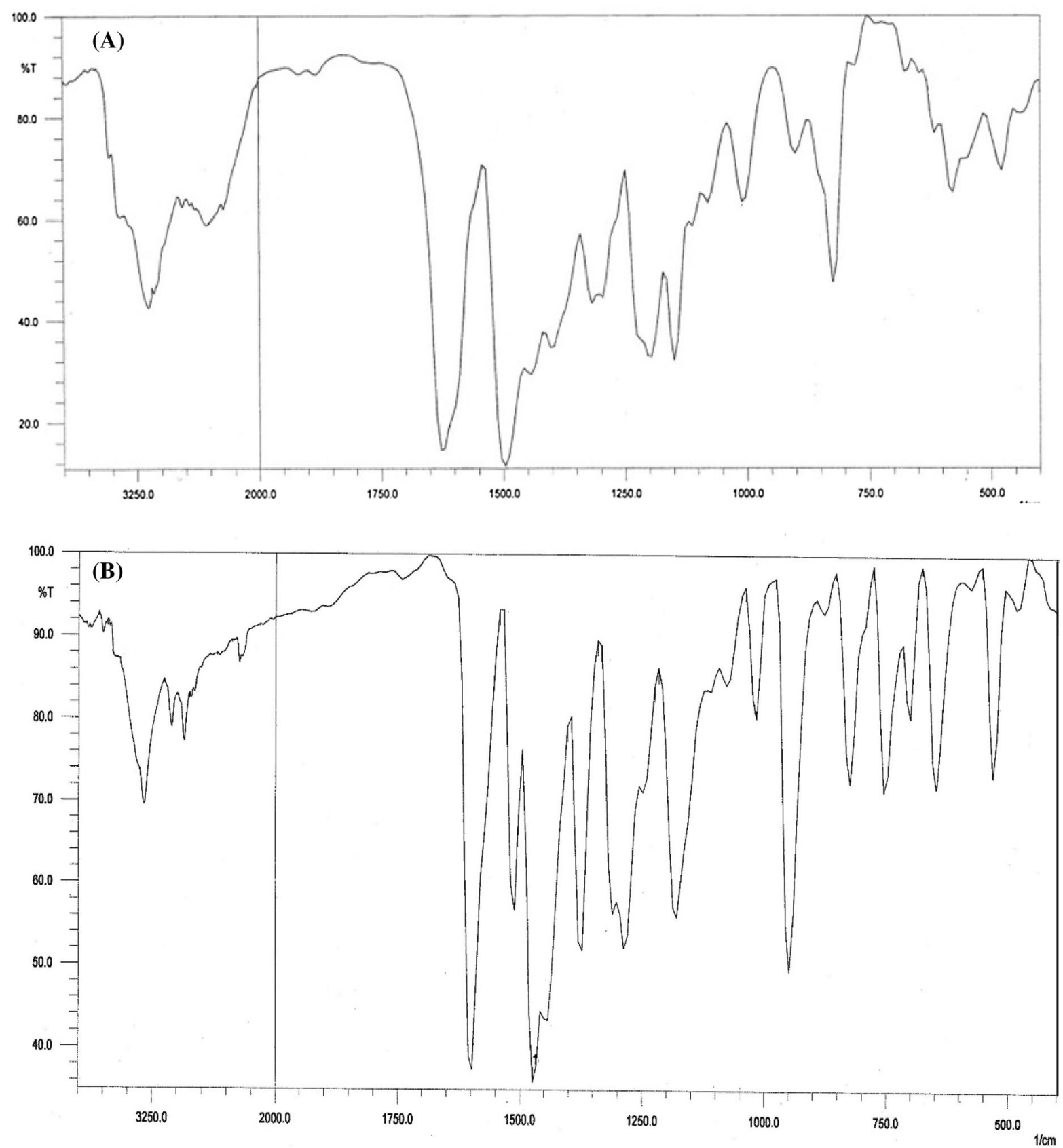

Fig. 1 Demonstrates FTIR spectrum of $\mathrm{H}_{2} \mathrm{~L}(\mathbf{a})$, FTIR spectrum of [IV(L)] (b)

$10 \mu \mathrm{L}$ of propidium iodide (PI) for $45 \mathrm{~min}$. The stained and un-stained cells were analyzed using Cyflow $^{\circledR}$ space flow cytometer (Partec, Münster, Germany). Flowmax software (Partec) was used for data analysis.
Evaluation of morphological changes in the treated cells

The treated cells were also evaluated regarding the alteration in cell morphology, which is a main result of apoptosis. Accordingly, morphological changes on 

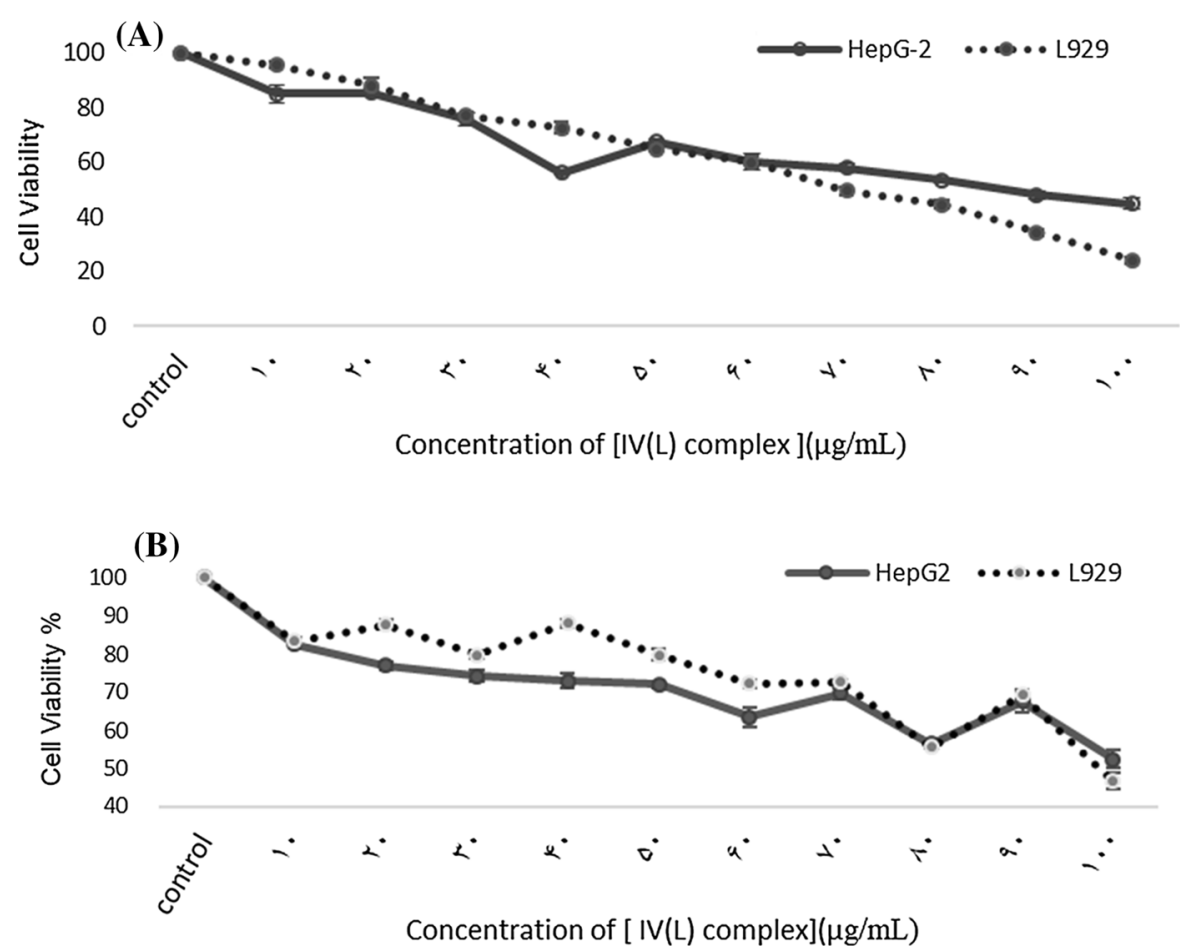

Fig. 2 Determination of IC50 in L929 and HepG2 cell lines after 24 and $48 \mathrm{~h}$ culture. a Illustrates the percent of cell viabilities in L929 and HepG2 cell line at $24 \mathrm{~h}$, b illustrates the percent of cell viabilities in L929 and HepG2 cell lines at $48 \mathrm{~h}$,

HepG2 and L929 cells after exposure to [IV(L)] complex were examined using an inverted microscope under $\times 400$ magnification. $P$ value of less than 0.05 was considered statistically significant.

\section{Statistical analysis}

After evaluation of raw data regarding Gaussian distribution, One Way ANOVA under SPSS software version 18 was used to analyze the data.

\section{Results}

The results demonstrated that although, the IC50 for both cell lines at $24 \mathrm{~h}$ was the same $(100 \mu \mathrm{g} / \mathrm{mL}$ or $0.17 \mu \mathrm{M})$, it was higher for HepG2 $(79 \mu \mathrm{g} / \mathrm{mL}$ or $0.14 \mu \mathrm{M})$ than $\mathrm{L} 929(69 \mu \mathrm{g} / \mathrm{mL}$ or $0.12 \mu \mathrm{M})$ at $48 \mathrm{~h}$. Based on the results it seems that L929 cells, as the normal liver cells, were more sensitive to [IV(L)] complex than the cancerous cells (HepG2). Compared with the clinical drug reference cisplatin with the IC50 respectively. MTT test revealed that IC50 for L929 cell line at 24 and $48 \mathrm{~h}$ were 100 and 69, respectively. IC50 for HepG2 cell line at $24 \mathrm{~h}$ was 100 and at $48 \mathrm{~h}$ was $79 \mu \mathrm{g} / \mathrm{mL}$. Cell viability in DMSO and control groups were $100 \%$

of $3.67 \mu \mathrm{g} / \mathrm{mL}(0.012 \mu \mathrm{M})$ at $48 \mathrm{~h}$, these values are large. However, the $[\mathrm{IV}(\mathrm{L})]$ complex can be considered and further studied as a potent anticancer agent.

The analysis of results showed that the $[\operatorname{IV}(\mathrm{L})]$ complex IC50 values for HepG2 cells at 24 and $48 \mathrm{~h}$ were $0.17 \mu \mathrm{M}$ or $100 \mu \mathrm{g} / \mathrm{mL}$ and $0.14 \mu \mathrm{M}$ or $79 \mu \mathrm{g} /$ $\mathrm{mL}$, respectively. The IC50 value for L929 cells at $24 \mathrm{~h}$ was $0.17 \mu \mathrm{M}$ or $100 \mu \mathrm{g} / \mathrm{mL}$ and at $48 \mathrm{~h}$ was 0 . $12 \mu \mathrm{M}$ or $69 \mu \mathrm{g} / \mathrm{mL}$ (Fig. 2). The morphologic images of L929 and HepG2 cell lines before and after treatment with $[\mathrm{IV}(\mathrm{L})]$ complex are presented in the Fig. 3.

Flowcytometry analysis revealed that early and necrosis/late apoptosis rates in the L929 control cells (Untreated) by [IV(L)] complex) were 0.20 and $0.05 \%$ after $24 \mathrm{~h}$ and 1.09 and $0.01 \%$ after $48 \mathrm{~h}$, respectively. However, early and necrosis/late apoptosis rates in the L929 cells which were under treatment of [IV(L)] complex in IC50 concentration were 48.75 and $1.97 \%$ after $24 \mathrm{~h}$ and 36.85 and $0.10 \%$ after $48 \mathrm{~h}$, respectively. 

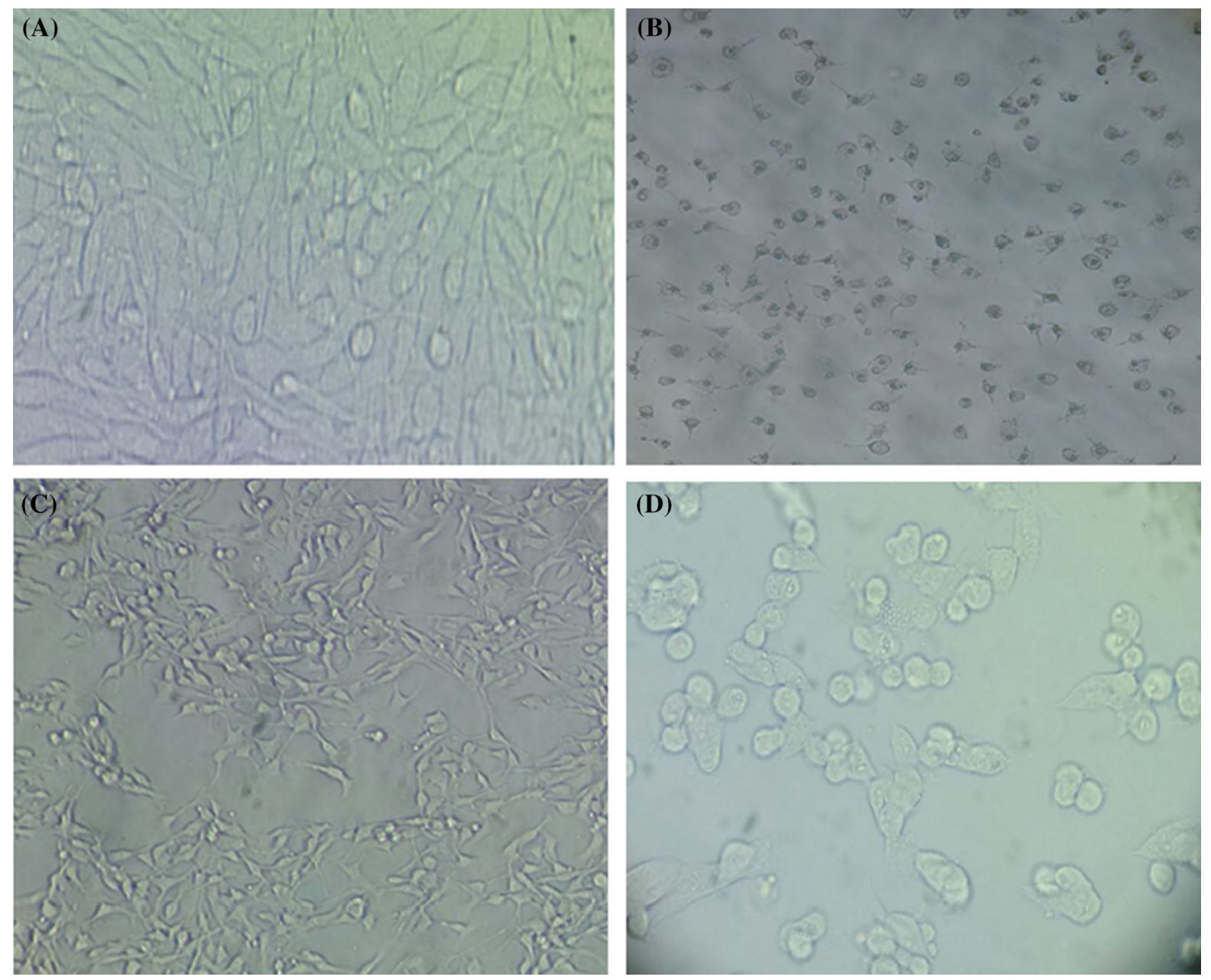

Fig. 3 Morphology of L929 and HepG2 cell lines before and after treatment with [IV(L)] complex. [IV(L)] complex induces apoptosis in both cell lines. a L929 control before treatment with

The early apoptosis rate in HepG2 control cells (without treatment with the $[\mathrm{IV}(\mathrm{L})]$ complex) at $24 \mathrm{~h}$ was $0.39 \%$, while its necrosis/late rate was $0.02 \%$. Early and necrosis/late apoptosis rates in HepG2 control cells at $48 \mathrm{~h}$ were $1.24 \%$ and 0.60 , respectively. Additionally, early (44.96\%) and necrosis/late (4.35\%) apoptosis rates in HepG2 treated cells at $24 \mathrm{~h}$ were significantly increased by the $[\mathrm{IV}(\mathrm{L})]$ complex. Evaluation of early and necrosis/late apoptosis rates in HepG 2 treated cells after $48 \mathrm{~h}$ also demonstrated that the rates of early $(51.69 \%)$ and necrosis/late $(28.36 \%)$ apoptosis rates were increased significantly (Fig. 4 and Table 1).

IV complex. b L929 after treatment with [IV(L)] complex. c HepG2 control before treatment with [IV(L)] complex and d HepG2 after treatment with [IV(L)] complex, respectively

\section{Discussion}

HCC is a prevalent cancer, especially in the viral hepatitis endemic region (Winters et al. 2017; Tervonen et al. 2017). It has been reported that HCC showed drug resistance in some cases (Galun et al. 2017; Dong et al. 2017; Guo et al. 2014) and, hence, investigators are studying new drug candidate to treat the malignancy. However, side effects of the chemical drugs are the main limitations of using these drugs (Yan et al. 2014).

The results demonstrated that although, the IC50 for both cell lines at $24 \mathrm{~h}$ was the same $(100 \mu \mathrm{g} / \mathrm{mL}$ or $0.17 \mu \mathrm{M})$, it was higher for HepG2 $(79 \mu \mathrm{g} / \mathrm{mL}$ or $0.14 \mu \mathrm{M})$ than $\mathrm{L} 929(69 \mu \mathrm{g} / \mathrm{mL}$ or $0.12 \mu \mathrm{M})$ at $48 \mathrm{~h}$. 

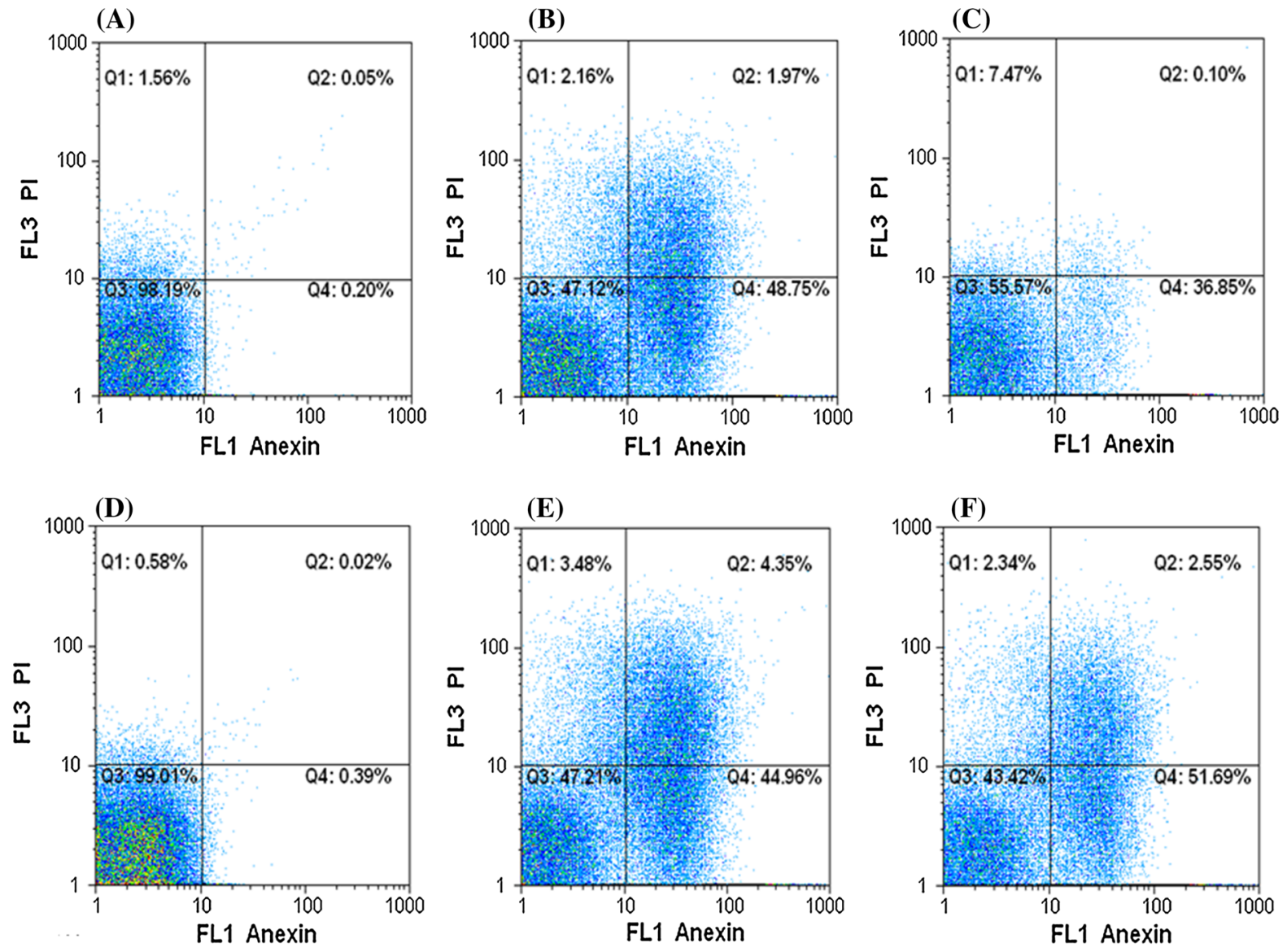

Fig. 4 Flow cytometry analysis of HepG2 and L929 cells treated with [IV(L)] complex. Un-treated [IV(L)] complex cells (a), HepG2 cells treated at IC50 concentration $(100 \mu \mathrm{g} / \mathrm{mL})$ of [IV(L)] complex for $24 \mathrm{~h}$ (b), HepG2 treated at IC50 concentration $(79 \mu \mathrm{g} / \mathrm{mL})$ of $[\mathrm{IV}(\mathrm{L})]$ complex for $48 \mathrm{~h}(\mathbf{c})$, untreated L929 cells (d), L929 treated at IC50 concentration $(100 \mu \mathrm{g} / \mathrm{mL})$ of $[\mathrm{IV}(\mathrm{L})]$ complex for $24 \mathrm{~h}(\mathbf{e})$, and L929 cells treated at IC50 concentration $(69 \mu \mathrm{g} / \mathrm{mL})$ of $[\mathrm{IV}(\mathrm{L})]$ complex for $48 \mathrm{~h}$ (f) stained with Annexin V-fluorescein isothiocyanate (FITC) and propidium iodide (PI). Subsequently, apoptotic and necrotic cells were quantified by flow cytometry. The different subpopulations were defined as Q1 annexin V-negative but PIpositive, i.e. necrotic cells; Q2 annexin V/PI double positive, i.e. late apoptotic cells; Q3 annexin V/PI double negative, i.e. normal live cells; Q4 annexin V-positive but PI negative, i.e. apoptotic cells

Table 1 Apoptosis percentage at IC50 concentration of [IV(L)] complex $(\mu \mathrm{m} / \mathrm{mL})$

\begin{tabular}{llccrc}
\hline Apoptosis rates & \multicolumn{2}{l}{ HepG2 } & & \multicolumn{2}{l}{ L929 } \\
\cline { 2 - 3 } \cline { 5 - 6 } & $24 \mathrm{~h}(100 \mu \mathrm{g} / \mathrm{mL})(\%)$ & $48 \mathrm{~h}(79 \mu \mathrm{g} / \mathrm{mL})(\%)$ & & $24 \mathrm{~h}(100 \mu \mathrm{g} / \mathrm{mL})(\%)$ & $48 \mathrm{~h}(69 \mu \mathrm{g} / \mathrm{mL})(\%)$ \\
\hline Normal live cells & 47.21 & 43.42 & 47.12 & 55.57 \\
Early apoptosis cells & 4.35 & 2.55 & 1.97 & 0.10 \\
Late apoptosis cells & 44.96 & 51.69 & 48.75 & 36.85 \\
Necrosis cells & 3.48 & 2.34 & 2.16 & 7.47 \\
\hline
\end{tabular}

Based on the results it seems that L929 cells, as the normal liver cells, were more sensitive to [IV(L)] complex than the cancerous cells (HepG2). Compared with the clinical drug reference cisplatin with the IC50 of $3.67 \mu \mathrm{g} / \mathrm{mL}(0.012 \mu \mathrm{M})$ at $48 \mathrm{~h}$, these values are large. However, the $[\mathrm{IV}(\mathrm{L})]$ complex can be 
considered and further studied as a potent anticancer agent (Leon et al. 2017a; León et al. 2016; Sciortino et al. 2018; Ebrahimipour et al. 2015; Abbasi et al. 2017; Hong et al. 2017; Schmidt et al. 2017; Sheikhshoaie et al. 2016; Ebrahimipour et al. 2016; Nair et al. 2016; Takjoo et al. 2013; Takjoo et al. 2017; Heidari et al. 2017; Zabin and Abdelbaset 2016; Mohamadi et al. 2015).

In order to conclude the efficacy of [IV(L)] complex to be considered as a potential candidate for cancer therapy need to have a look to the results obtained from apoptosis and necrosis results. Accordingly, our results showed that the $[\mathrm{IV}(\mathrm{L})]$ complex induces early and necrosis/late apoptosis rates in both cancer and normal cell lines. However, the rate of apoptosis, especially early apoptosis, was significantly higher in the HepG2 cells after $48 \mathrm{~h}$ incubation with [IV(L)] complex when compared to early apoptosis in the L929, the normal cell line, cells. Due to the fact that induction of early apoptosis is an important key factor for anti-cancer components, hence, based on the results, it appears that $[\mathrm{IV}(\mathrm{L})]$ complex can be considered as a potential drug to induce apoptosis in liver tumor cells with lower side effects on normal cells. Additionally, the early apoptosis was higher especially in the HepG2 cell lines when it was incubated with [IV(L)] complex at $48 \mathrm{~h}$. It confirms that more exposure to [IV(L)] complex can induce apoptosis in the cancerous cell lines. Interestingly, the results also showed that necrosis/late apoptosis were also higher in HepG2 cells than L929 cells and in another word, just $0.1 \%$ of the L929 cell line suffered from necrosis/late apoptosis (it was $28.36 \%$ for HepG2 cells). Based on the fact that necrosis is an inflammatory condition which leads to infiltration of immune cells to the necrotic tissue and consequently leads to immune-related tissue injuries, it may be concluded that $[\mathrm{IV}(\mathrm{L})]$ complex probably can be considered as a new HCC treatment strategy because on induction of inflammation in the HCC tissue without injuries to normal cell. To the best of our knowledge, this project is the first investigation on the biological activity of [IV(L)] complex as a novel anticancer agent. However, to confirm the anti-cancer effects of the complex, further investigations especially in the in vivo condition need to be performed to prove the anti-cancer roles of $[\mathrm{IV}(\mathrm{L})]$ complex and also its safety. In parallel with our results, Nair et al. reported that nicotinoyl hydrazones component of vanadium induces apoptosis in $\mathrm{SiHa}$ and $\mathrm{HeLa}$ cancerous cell lines via up-regulation of p53, the well-known pro-apoptotic protein (Nair et al. 2014). $\mathrm{Wu}$ and colleagues also revealed that Sodium orthovanadate, another component of Vanadium, suppresses human HCC cells in both in vitro and orthotopic in vivo model via modulation of proliferation, cell cycle, apoptosis and autophagy (Wu et al. 2014). The cancer prevention roles played by vanadium were also demonstrated by Mandair et al. (2014) and Bishayee et al. (1997). Interestingly, Kowalski et al. reported that vanadium complexes not only induces apoptosis in human pancreatic ductal adenocarcinoma cell line, but also leads to induction of necroptosis in the cell lines (Kowalski et al. 2017). Our results also showed that the $[\mathrm{IV}(\mathrm{L})]$ complex can induce apoptosis in HepG2 cell lines more than L929 cells, and also induces necrosis/late apoptosis in HepG2 cells higher than normal liver cells which can be associated with anti-cancer inflammation. Therefore, our results confirmed the apoptotic and necrotic roles played by vanadium complexes against the cancers. Additionally, based on the results, L929 cells were more sensitive than HepG2 to [IV(L)] complex and have lower IC50 at $48 \mathrm{~h}$ incubation. Based on the investigation by Wang et al. (2010) which demonstrated that using antioxidants has synergistic effects with vanadium to kill cancer cells and also reduce their toxicities on human normal cells, it may propose that using $[\mathrm{IV}(\mathrm{L})]$ complex in association with antioxidants materials can reduce $\mathrm{L} 929$ sensitivities.

Collectively, our results may propose that [IV(L)] complex can be considered as a new strategy for treatment of HCC which need to be evaluated in the in vivo condition. Based on the Wang et al. study, it may also be hypothesized that $[\mathrm{IV}(\mathrm{L})]$ complex may be modified by co-administration of antioxidant to be safer than its administration alone.

Acknowledgements This article is an excerpt from Hamid Bakhshialiabad's PhD's thesis in Molecular Medicine Research Center, Rafsanjan University of Medical Sciences (RUMS), Rafsanjan, Iran. Authors have a chance to thanks to Molecular Medicine Research Center staffs, Rafsanjan University of Medical Sciences for their warmly corporations.

Funding This study was supported by the RUMS by the Grant Number (1396.3.2-449) and ethical code: IR.RUMS.REC.1396.50 from the Rafsanjan University of Medical Sciences, Iran. 


\section{Compliance with ethical standards}

Conflict of interest The authors report no conflict of interest.

Ethical approval This article does not contain any studies with human participants or animals performed by any of the authors.

Informed consent This article does not contain any studies with human participants.

Open Access This article is distributed under the terms of the Creative Commons Attribution 4.0 International License (http:// creativecommons.org/licenses/by/4.0/), which permits unrestricted use, distribution, and reproduction in any medium, provided you give appropriate credit to the original author(s) and the source, provide a link to the Creative Commons license, and indicate if changes were made.

\section{References}

Abbasi Z, Salehi M, Kubicki M, Khaleghian A (2017) Crystal structures, electrochemical properties, antioxidant screening and in vitro cytotoxic studies on four novel $\mathrm{Cu}$ (II) complexes of bidentate Schiff base ligands derived from 2-methoxyethylamine. J Coord Chem 70:2074-2093

Bagrezaei F, Hassanshahi G, Mahmoodi M, Falahati-Pour SK, Mirzaei MR (2018) Expression of inhibitor of apoptosis gene family members in bladder cancer tissues and the 5637 tumor cell line. Asian Pacif J Cancer Prev 19:529

Bishayee A, Karmakar R, Mandal A, Kundu SN, Chatterjee M (1997) Vanadium-mediated chemoprotection against chemical hepatocarcinogenesis in rats: haematological and histological characteristics. Eur J Cancer Prev 6:58-70

Ceylan C, Kantar M, Tuna A, Ertam I, Aksoylar S, Gunaydin A, Cetingul N (2015) Cutaneous side effects of chemotherapy in pediatric oncology patients. Cutis 95:11-16

Clavagnier I (2014) Preventing the side effects of chemotherapy. Rev Infirm 198:49-50

Dong J, Zhai B, Sun W, Hu F, Cheng H, Xu J (2017) Activation of phosphatidylinositol 3-kinase/AKT/snail signaling pathway contributes to epithelial-mesenchymal transitioninduced multi-drug resistance to sorafenib in hepatocellular carcinoma cells. PLoS ONE 12:e0185088

Ebrahimipour SY, Sheikhshoaie I, Kautz AC, Ameri M, PasbanAliabadi H, Rudbari HA, Bruno G, Janiak C (2015) Monoand dioxido-vanadium (V) complexes of a tridentate ONO Schiff base ligand: synthesis, spectral characterization, $\mathrm{X}$-ray crystal structure, and anticancer activity. Polyhedron 93:99-105

Ebrahimipour SY, Sheikhshoaie I, Simpson J, Ebrahimnejad H, Dusek M, Kharazmi N, Eigner V (2016) Antimicrobial activity of aroylhydrazone-based oxido vanadium (v) complexes: in vitro and in silico studies. New J Chem 40:2401-2412

Galun D, Srdic-Rajic T, Bogdanovic A, loncar Z, Zuvela M (2017) Targeted therapy and personalized medicine in hepatocellular carcinoma: drug resistance, mechanisms, and treatment strategies. J Hepatocell Carcinoma 4:93-103
Guo YL, Kong QS, Liu HS, Tan WB (2014) Drug resistance effects of ribosomal protein L24 overexpression in hepatocellular carcinoma HepG2 cells. Asian Pac J Cancer Prev 15:9853-9857

Han W, Hou G, Liu L (2015) Polyphyllin I (PPI) increased the sensitivity of hepatocellular carcinoma HepG2 cells to chemotherapy. Int J Clin Exp Med 8:20664-20669

Heidari F, Fatemi SJA, Ebrahimipour SY, Ebrahimnejad H, Castro J, Dušek M, Eigner V (2017) Six-coordinate oxovanadium (V) dimer complex with methoxy bridging: Synthesis, crystal structure, biological activity and molecular docking. Inorg Chem Commun 76:1-4

Ho DW, Lo RC, Chan LK, Ng IO (2016) Molecular pathogenesis of hepatocellular carcinoma. Liver Cancer 5:290-302

Hong X-L, Zeng M-H, Liu L-J, Ye X-L, Yi D-S (2017) Synthesis, characterization and in vitro antitumor behavior of a vanadium (V) complex with $4^{\prime}$-(3-methoxyphenyl)-2, $2^{\prime}: 6^{\prime}$ $2^{\prime \prime}$-terpyridine. J Coord Chem 70:1438-1450

Hosseini FS, Falahati-Pour SK, Hajizadeh MR, Khoshdel A, Mirzaei MR, Ahmadirad H, Behroozi R, Jafari N, Mahmoodi M (2017) Persian shallot, Allium hirtifolium Boiss, induced apoptosis in human hepatocellular carcinoma cells. Cytotechnology 69:551-563

Karimabad MN, Mahmoodi M, Jafarzadeh A, Darehkordi A, Hajizadeh MR, Khorramdelazad H, Falahati-Pour SK, Hassanshahi G (2017) The novel indole-3-formaldehyde (2-AITFEI-3-F) is involved in processes of apoptosis induction? Life Sci 181:31-44

Kowalski S, Hac S, Wyrzykowski D, Zauszkiewicz-Pawlak A, Inkielewicz-Stepniak I (2017) Selective cytotoxicity of vanadium complexes on human pancreatic ductal adenocarcinoma cell line by inducing necroptosis, apoptosis and mitotic catastrophe process. Oncotarget 8:60324-60341

Le Grazie M, Biagini MR, Tarocchi M, Polvani S, Galli A (2017) Chemotherapy for hepatocellular carcinoma: the present and the future. World J Hepatol 9:907-920

Leon IE, Cadavid-Vargas JF, Di Virgilio AL, Etcheverry SB (2017a) Vanadium, ruthenium and copper compounds: a new class of nonplatinum metallodrugs with anticancer activity. Curr Med Chem 24:112-148

Leon IE, Diez P, Baran EJ, Etcheverry SB, Fuentes M (2017b) Decoding the anticancer activity of VO-clioquinol compound: the mechanism of action and cell death pathways in human osteosarcoma cells. Metallomics 9:891-901

Leon IE, Diez P, Etcheverry SB, Fuentes M (2016) Deciphering the effect of an oxovanadium(iv) complex with the flavonoid chrysin (VOChrys) on intracellular cell signalling pathways in an osteosarcoma cell line. Metallomics 8:739-749

León IE, Díez P, Etcheverry SB, Fuentes M (2016) Deciphering the effect of an oxovanadium (iv) complex with the flavonoid chrysin (VOChrys) on intracellular cell signalling pathways in an osteosarcoma cell line. Metallomics 8:739-749

Mandair DS, Rossi RE, Pericleous M, Whyand T, Caplin M (2014) The impact of diet and nutrition in the prevention and progression of hepatocellular carcinoma. Expert Rev Gastroenterol Hepatol 8:369-382

Mohamadi M, Ebrahimipour SY, Torkzadeh-Mahani M, Foro S, Akbari A (2015) A mononuclear diketone-based oxidovanadium (IV) complex: structure, DNA and BSA binding, 
molecular docking and anticancer activities against MCF7, HPG-2, and HT-29 cell lines. RSC Adv 5:101063-101075

Mohammadizadeh F, Falahati-Pour SK, Rezaei A, Mohamadi M, Hajizadeh MR, Mirzaei MR, Mahmoodi M (2018) The cytotoxicity effects of a novel $\mathrm{Cu}$ complex on MCF-7 human breast cancerous cells. Biometals 31:233-242

Nair RS, Kuriakose M, Somasundaram V, Shenoi V, Kurup MR, Srinivas P (2014) The molecular response of vanadium complexes of nicotinoyl hydrazone in cervical cancers-a possible interference with HPV oncogenic markers. Life Sci 116:90-97

Nair YS, Kurup MP, Nair SM (2016) Spectral investigation and crystal structures of some transition of metal complex of aroylhydrazones. Cochin University of Science and Technology, Kochi

Obeid JM, Kunk PR, Zaydfudim VM, Bullock TN, Slingluff CL Jr, Rahma OE (2017) Immunotherapy for hepatocellular carcinoma patients: is it ready for prime time? Cancer Immunol Immunother 20:017-2082

Ramezani M, Ramezani M, Hassanshahi G, Mahmoodi M, Zainodini N, Darekordi A, Falahati-Pour SK, Mirzaei MR (2017) Does the novel class of (2R, 4S)-N-(2, 5-difluorophenyl)-4-hydroxy-1-(2, 2, 2-trifluoroacetyl) pyrrolidine-2-carboxamide's have any effect on cell viability and apoptosis of human hepatocellular carcinoma cells? Int J Cancer Manag 10:e8413

Schmidt A-C, Hermsen M, Rominger F, Dehn R, Teles JH, Schäfer A, Trapp O, Schaub T (2017) Synthesis of monoand dinuclear vanadium complexes and their reactivity toward dehydroperoxidation of alkyl hydroperoxides. Inorg Chem 56:1319-1332

Sciortino G, Sanna D, Ugone V, Lledós A, Maréchal J-D, Garribba E (2018) Decoding surface interaction of VIVO metallodrug candidates with lysozyme. Inorg Chem 57:4456-4469

Sheikhrezaei Z, Heydari P, Farsinezhad A, Fatemi A, Khanamani Falahati-Pour S, Darakhshan S, Noroozi Karimabad M, Darekordi A, Khorramdelazad H, Hassanshahi G (2018) A new indole derivative decreased SALL4 gene expression in acute promyelocytic leukemia cell line (NB4). Iran Biomed J 22:99-106

Sheikhshoaie I, Ebrahimipour SY, Lotfi N, Mague JT, Khaleghi M (2016) Synthesis, spectral characterization, X-ray crystal structure and antimicrobial activities of two cis dioxido-vanadium (V) complexes incorporating unsymmetrical dimalonitrile-based (NNO) Schiff base ligands. Inorg Chim Acta 442:151-157

Shiba S, Abe T, Shibuya K, Katoh H, Koyama Y, Shimada H, Kakizaki S, Shirabe K, Kuwano H, Ohno T, Nakano T (2017) Carbon ion radiotherapy for 80 years or older patients with hepatocellular carcinoma. BMC Cancer 17:721

Takjoo R, Akbari A, Ebrahimipour SY, Kubicki M, Mohamadi M, Mollania N (2017) Synthesis, spectral characterization, DFT calculations, antimicrobial activity and molecular docking of 4-bromo-2-((2-hydroxy-5-methylphenylimino) methyl) phenol and its $\mathrm{V}(\mathrm{V})$ complex. Inorg Chim Acta 455:173-182

Takjoo R, Mague JT, Akbari A, Ebrahimipour SY (2013) Synthesis, structural, and thermal analyses of copper(II) and oxido-vanadium(IV) complexes of 4-bromo-2-(((5chloro-2-hydroxyphenyl)imino)methyl)phenol. J Coord Chem 66:2852-2862

Tervonen H, Foliaki S, Bray F, Roder D (2017) Cancer epidemiology in the small nations of Pacific Islands. Cancer Epidemiol 50:184-192

Wang Q, Liu TT, Fu Y, Wang K, Yang XG (2010) Vanadium compounds discriminate hepatoma and normal hepatic cells by differential regulation of reactive oxygen species. J Biol Inorg Chem 15:1087-1097

Winters S, Martin C, Murphy D, Shokar NK (2017) Breast cancer epidemiology, prevention, and screening. Prog Mol Biol Transl Sci 151:1-32

Wu Y, Ma Y, Xu Z, Wang D, Zhao B, Pan H, Wang J, Xu D, Zhao X, Pan S, Liu L, Dai W, Jiang H (2014) Sodium orthovanadate inhibits growth of human hepatocellular carcinoma cells in vitro and in an orthotopic model in vivo. Cancer Lett 351:108-116

Yan F, Bai LP, Gao H, Zhu CM, Lin L, Kang XP (2014) EGF reverses multi-drug resistance via the p-ERK pathway in HepG2/ADM and SMMC7721/ADM hepatocellular carcinoma models. Asian Pacif J Cancer Prev 15:2619-2623

Zabin SA, Abdelbaset M (2016) Oxo/dioxo-vanadium (V) complexes with Schiff base ligands derived from 4-amino-5-mercapto-3-phenyl-1, 2, 4-triazole. Eur J Chem $7: 322-328$

Zainodini N, Hassanshahi G, Hajizadeh MR, Falahati-Pour S, Mahmoodi M, Mirzaei MR (2018) Nisin induces cytotoxicity and apoptosis in human asterocytoma cell line (SW1088). Asian Pacif J Cancer Prev 19:2217-2222 